\title{
PENGEMBANGAN BUKU AJAR AKUNTANSI BERBASIS INTEGRASI- INTERKONEKSI UNTUK KELAS XI IPS DI MAN 3 MALANG
}

\author{
Fikryyah Dwi Cahyani \\ FE Universitas Negeri Malang \\ fikryyah.cahyani@gmail.com
}

\begin{abstract}
This study aims to produce an integration-interconnection based accounting textbook as alternative learning material for teacher and the eleventh grade student of social studies at MAN 3 Malang and find out the effectiveness of the use of integration-interconnection based accounting textbook. This study is a Research and Development which refers and modifies Borg and Gall development procedures. Data in this study were gathered using questionnaire and test and also analyzed using descriptive percentage analysis and t-test (paired-samples $t$ test). The results shows that overall the average percentage of worthiness of the textbook is $86.71 \%$. This indicates that textbook has a valid criterion and worthy used. Based on t-test (paired-samples t test) known there is a difference in motivation and learning outcomes of students before and after given the treatment an integration-interconnection based accounting textbook which indicates that textbook is influential effective.
\end{abstract}

Keywords: Developing, Textbook, Accounting, Integration-Interconnection

\begin{abstract}
Abstrak: Penelitian ini bertujuan untuk menghasilkan buku ajar akuntansi berbasis integrasi-interkoneksi sebagai alternatif bahan ajar untuk guru dan siswa kelas XI IPS di MAN 3 Malang serta mengetahui efektivitas penggunaan buku ajar akuntansi berbasis integrasi-interkoneksi. Penelitian ini merupakan penelitian pengembangan yang mengacu dan memodifikasi prosedur pengembangan Borg and Gall. Data dalam penelitian ini dikumpulkan dengan menggunakan angket dan tes serta dianalisis menggunakan analisis deskriptif persentase dan uji $\mathrm{t}$ (paired-samples $t$ test). Hasil penelitian menunjukkan secara keseluruhan rata-rata persentase kelayakan buku ajar sebesar $86.71 \%$. Hal ini menunjukkan bahwa buku ajar yang dikembangkan memiliki kriteria valid dan layak untuk digunakan. Berdasarkan hasil uji t (paired-samples $t$ test) diketahui terdapat perbedaan motivasi dan hasil belajar siswa sebelum dan sesudah diberikan treatment berupa buku ajar akuntansi berbasis integrasi-interkoneksi yang menandakan bahwa buku ajar berpengaruh efektif.
\end{abstract}

Keywords: Pengembangan, Buku Ajar, Akuntansi, Integrasi-Interkoneksi

Islam adalah agama ilmu dan akal, karena itu sebelum Islam membebankan penganut-penganutnya agar menghasilkan maksud keduniaan, terlebih dahulu membebankan mereka supaya menjadi orang yang berakal sehat, cemerlang pikiran, bagus penglihatan, dapat memikirkan dan mempertimbangkan dengan 
matang segala urusan sebelum mengerjakannya, supaya perbuatannya bersesuaian dengan kebenaran, keadilan, kemaslahatan, dan kewajiban. Islam juga membebankan penganut-penganutnya agar menjadi orang yang berpengetahuan, yaitu dengan mengetahui segala sebab kemaslahatan dan jalan-jalan kemanfaatan, menyelami hakikat alam, meninjau dan menganalisa segala pengalaman umat yang terdahulu, baik yang berkenaan dengan 'aqa'id dan ibadat, maupun yang berkaitan dengan keluhuran budi, sosial ekonomi serta ilmu pengetahuan alam, dan sebagainya (Ash Shiddieqy, 1998a:611).

Direktorat Pendidikan Madrasah Kementerian Agama Republik Indonesia (2013) mengembangkan pendidikan madrasah baik program maupun lembaga pendidikannya agar mempunyai ciri khas yang menjadi keunikan komparatif (comparative uniqueness) dari sub sistem pendidikan nasional lainnya. Salah satunya dengan mengembangkan pendidikan madrasah yang bersifat holistik, yaitu dengan memadukan pengembangan manusia seutuhnya antara aspek jasmani dan rohani; akidah, ibadah, muamalah, akhlakul karimah; ilmu agama dan ilmu pengetahuan juga teknologi; nilai tradisi dan modern; serta kearifan lokal dalam dinamika global. Di lain pihak, selaras dengan maksud pernyataan di atas, kurikulum 2013 memiliki beberapa karakteristik salah satunya yaitu mengembangkan keseimbangan antara pengembangan sikap spiritual dan sosial, rasa ingin tahu, kreativitas, kerja sama dengan kemampuan intelektual dan psikomotorik. Dalam struktur kurikulum 2013 terdapat kurikulum inti yang dirancang dalam empat kelompok yang saling terkait yaitu sikap keagamaan (kompetensi inti 1), sikap sosial (kompetensi inti 2), pengetahuan (kompetensi inti 3), dan penerapan pengetahuan (kompetensi inti 4). Keempat kelompok itu menjadi acuan dari Kompetensi Dasar (KD) dan harus dikembangkan dalam setiap peristiwa pembelajaran secara integratif (Notodiputro, 2013). Dari beberapa uraian diatas, peneliti menyimpulkan bahwa selain mempelajari ilmu pengetahuan manusia juga dituntut untuk mempelajari ilmu agama. Terlebih lagi untuk memadukan maupun mengaitkan keduanya dalam pembelajaran secara integratif seperti yang diuraikan dalam struktur kurikulum 2013 dan pada ciri pendidikan madrasah yang bersifat holistik. 
Di samping itu Ash Shiddieqy (1998a:612) mengungkapkan bahwa mempelajari hukum-hukum muamalah dalam Islam hukumnya adalah perlu. Halhal yang termasuk dalam muamalah antar sesama manusia menurut Ash Shiddieqy (1998b:191) diantaranya adalah perniagaan, sewa-menyewa, pertanian, dan pertukangan. Akuntansi merupakan salah satu teknologi bermuamalah yang sangat penting dalam kehidupan seiring semakin pentingnya peranan uang (moneter) dalam bermuamalah (Warsono, 2012:87,137). Di samping itu Warsono (2012:137) menyebutkan bahwa dalam Alquran terdapat banyak ayat yang menginformasikan, secara langsung maupun tidak langsung, tentang akuntansi. Salah satunya yaitu dalam surah Al-Baqarah ayat 282 yang sering diidentikkan dengan keberadaan dan arti penting akuntansi. Oleh karena pentingnya mempelajari hukum muamalah yang merupakan ilmu agama dan akuntansi yang merupakan ilmu pengetahuan dunia serta didasari oleh struktur kurikulum 2013 dan ciri khas pendidikan madrasah yang bersifat holistik, maka peneliti menyimpulkan harus ada sinergi diantara keduanya yang disebut dengan istilah paradigma integrasi-interkoneksi.

Paradigma integrasi-interkoneksi dipelopori dan digagas oleh Abdullah (2007) ini merupakan usaha untuk menjadikan sebuah keterhubungan antara keilmuan agama dan keilmuan umum yang tergabung dalam ilmu alam, ilmu sosial, dan humaniora (Abdullah, dkk., 2007:53). Diharapkan dengan adanya pembelajaran berparadigma integrasi-interkoneksi yang menyajikan dan mengaitkan ayat-ayat Alquran dan Hadis dengan mata pelajaran akuntansi siswa lebih memiliki motivasi belajar yang tinggi sehingga prestasi belajar pun juga meningkat. Hal ini sesuai dengan pernyataan Uno (2009:35, 23) bahwa teknik motivasi yang dapat dilakukan dalam pembelajaran salah satunya adalah dengan menggunakan kaitan yang unik dan tak terduga untuk menerapkan suatu prinsip atau konsep yang telah dipahami, sehingga motivasi belajar dapat timbul karena adanya kegiatan yang menarik dalam belajar. Didukung pula oleh teori medan (dalam Sanjaya, 2011:123) yang menyebutkan bahwa motivasi itu penting untuk mendorong individu untuk belajar serta teori belajar Gestalt (dalam Sanjaya, 2011:120) yang menyatakan bahwa insight atau pemahaman antarbagian di dalam suatu situasi atas permasalahan, memegang peranan yang penting dalam perilaku. 
Dalam proses pembelajaran, hendaknya peserta didik memiliki kemampuan insight yaitu kemampuan mengenal keterkaitan unsur-unsur dalam suatu obyek atau peristiwa.

Berdasarkan hasil observasi di Madrasah Aliyah Negeri (MAN) 3 Malang, guru-guru mata pelajaran ekonomi yang tergabung dalam Musyawarah Guru Mata Pelajaran (MGMP) Ekonomi MAN 3 Malang telah menyusun perangkat pembelajaran, diantaranya silabus dan Rencana Pelaksanaan Pembelajaran (RPP) dengan nilai-nilai karakter Qurani, yang di dalamnya sudah memuat kandungan Alquran dan Hadis yang terkait dengan Standar Kompetensi (SK) dan KD. Namun kenyataannya dalam proses pembelajaran dikelas, guru belum menyampaikan dan menghubungkan materi dengan Alquran dan Hadis. Hal ini dikarenakan belum ada sumber belajar yang menghubungkan antara akuntansi dengan Alquran dan Hadis.

Berdasarkan uraian di atas maka pengembangan bahan ajar akuntansi berbasis integrasi-interkoneksi perlu dilakukan, hal ini dikarenakan bahan ajar akuntansi berbasis integrasi-interkoneksi belum tersedia khususnya di MAN 3 Malang dan karakterisitik sekolah sudah memenuhi apabila dilakukan model pembelajaran berbasis integrasi-interkoneksi. Oleh karena itu penelitian ini bertujuan untuk menghasilkan produk berupa buku ajar akuntansi berbasis integrasi-interkoneksi sebagai salah satu alternatif bahan ajar untuk guru dan siswa kelas XI IPS di MAN 3 Malang dan mengetahui efektivitas penggunaan buku ajar akuntansi berbasis integrasi-interkoneksi untuk siswa kelas XI IPS di MAN 3 Malang.

\section{METODE}

Model penelitian dan pengembangan dalam penelitian ini mengacu dan memodifikasi model pengembangan Borg and Gall (Borg, 1970a, 1970b) menjadi tujuh tahapan, yaitu: (1) penelitian dan pengumpulan data, (2) perencanaan, (3) pengembangan produk awal, (4) uji coba lapangan awal, (5) revisi produk hasil uji coba lapangan awal, (6) uji coba lapangan utama, (7) revisi produk akhir. Teknik pengumpulan data dalam penelitian ini menggunakan angket dan tes. Data yang diperoleh adalah data kuantitatif dan data kualitatif. Data kuantitatif berupa angka 
diperoleh dari angket validasi buku ajar yang digunakan untuk menentukan kelayakan dari buku ajar, angket motivasi siswa yang digunakan untuk mengukur motivasi siswa terhadap buku ajar, dan tes yang digunakan untuk mengetahui hasil belajar siswa. Data dari angket validasi buku ajar dianalisis dengan teknik analisis deskriptif persentase sedangkan data dari angket motivasi siswa dan tes dianalisis dengan menggunakan uji $\mathrm{t}$ (paired-samples $t$ test). Data kualitatif berupa komentar dan saran digunakan sebagai bahan pertimbangan dalam melakukan revisi produk. Untuk mengetahui keefektifan buku ajar yang telah dikembangkan maka dilakukan uji efektivitas dengan menggunakan desain eksperimen onegroup pretest-posttest design dengan membandingkan hasil pretest dan motivasi siswa sebelum diberikan buku ajar dengan posttest dan hasil belajar siswa setelah diberikan buku ajar.

\section{HASIL DAN PEMBAHASAN}

Pengembangan buku ajar akuntansi berbasis integrasi-interkoneksi ini dilakukan dalam tujuh tahapan. Tahap pertama adalah penelitian dan pengumpulan data. Pada tahap ini peneliti melakukan analisis kebutuhan dan studi pustaka. Berdasarkan hasil observasi pertama diketahui bahwa kurikulum yang digunakan di MAN 3 Malang adalah Kurikulum Tingkat Satuan Pendidikan (KTSP) untuk kelas XI dan XII, sedangkan untuk kelas X menggunakan Kurikulum 2013. Berkaitan dengan hal tersebut, sekolah mengembangkan sendiri silabus dan RPP untuk semua mata pelajaran termasuk ekonomi akuntansi. Pengembangan yang dilakukan mengacu pada pedoman yang telah ditetapkan oleh Badan Standar Nasional Pendidikan (BSNP) untuk kelas XI namun ditambah dengan memasukkan nilai-nilai karakter Qurani. Sehingga perangkat pembelajaran yang disusun mencantumkan ayat-ayat Alquran dan Hadis sebagai sumber belajar tambahan bagi siswa di samping materi pelajaran, khususnya akuntansi.

Kemudian berdasarkan hasil observasi kedua dengan mengamati kegiatan pembelajaran yang dilakukan oleh guru pamong di kelas XI IPS, diketahui bahwa bahan ajar utama dalam pelajaran akuntansi yang digunakan adalah buku paket ekonomi dan handout soal-soal latihan yang dibuat sendiri oleh guru akuntansi. 
Buku paket yang digunakan berisi materi yang dibutuhkan siswa sesuai dengan SK dan KD yang ada, namun tidak sesuai tujuan pembelajaran yang telah ditentukan dalam silabus dan RPP yang telah dikembangkan karena dalam buku paket tersebut tidak menyajikan ayat-ayat Alquran dan Hadis. Guru pamong juga belum menyampaikan kandungan ayat-ayat Alquran dan Hadis yang berkaitan dengan materi pelajaran akuntansi. Setelah melakukan analisis kebutuhan, peneliti melakukan studi pustaka dengan mengumpulkan literatur sehubungan dengan penyusunan buku ajar dengan cara menganalisis buku akuntansi yang digunakan di sekolah, mencari buku-buku yang memberikan informasi bagaimana cara mengaitkan antara materi pelajaran dengan Alquran dan Hadis, dan melakukan kajian terhadap penelitian terdahulu.

Tahap kedua adalah perencanaan. Dalam tahap ini peneliti telah memiliki rancangan produk yang akan dibuat yaitu bahan ajar berupa buku ajar akuntansi mata pelajaran ekonomi akuntansi untuk siswa kelas XI IPS yang disusun berdasarkan silabus dan RPP dari sekolah dengan memuat SK memahami penyusunan siklus akuntansi perusahaan jasa. Kemudian peneliti melanjutkan untuk menyusun pemetaan integrasi-interkoneksi, instrumen penilaian bahan ajar untuk melakukan validasi, instrumen untuk mengukur motivasi siswa, soal pretest dan posttest. Selanjutnya, sebelum buku ajar diujicobakan kepada siswa maka terlebih dahulu perlu dilakukan validasi buku ajar oleh validator yang terdiri dari satu orang ahli materi, satu orang ahli desain bahan ajar, dua orang ahli integrasiinterkoneksi, dan kelompok kecil subjek pengguna yaitu enam siswa dari kelas XI IPS 1 dan 2.

Tahap ketiga adalah pengembangan produk awal. Pada tahap ini peneliti mulai menyusun buku ajar akuntansi berbasis integrasi-interkoneksi yang terdiri dari beberapa fitur yaitu cover, kata pengantar, karakteristik buku ajar, daftar isi, cover bab, uraian materi, daftar pustaka, glosarium, indeks, dan biodata penulis. 


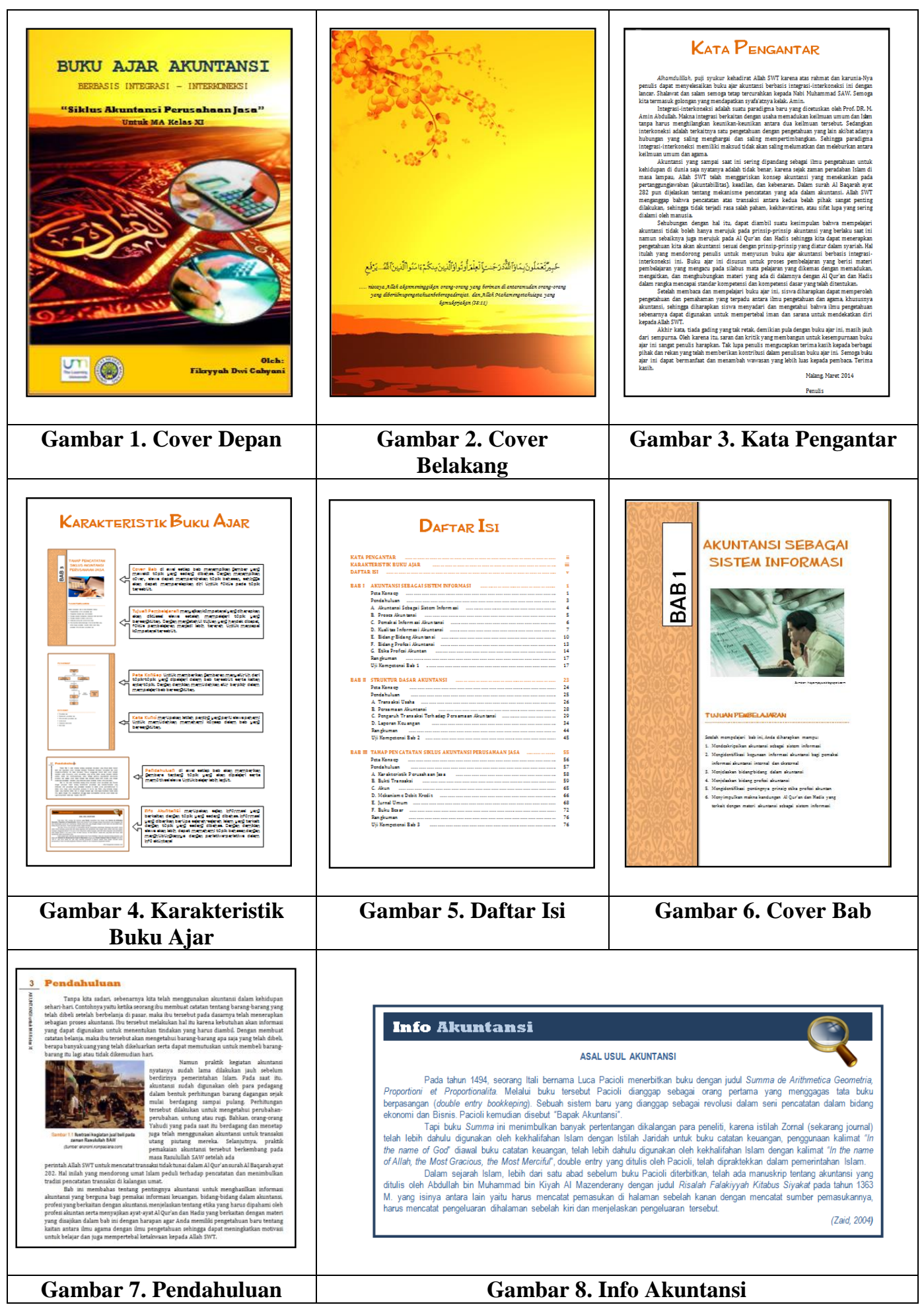




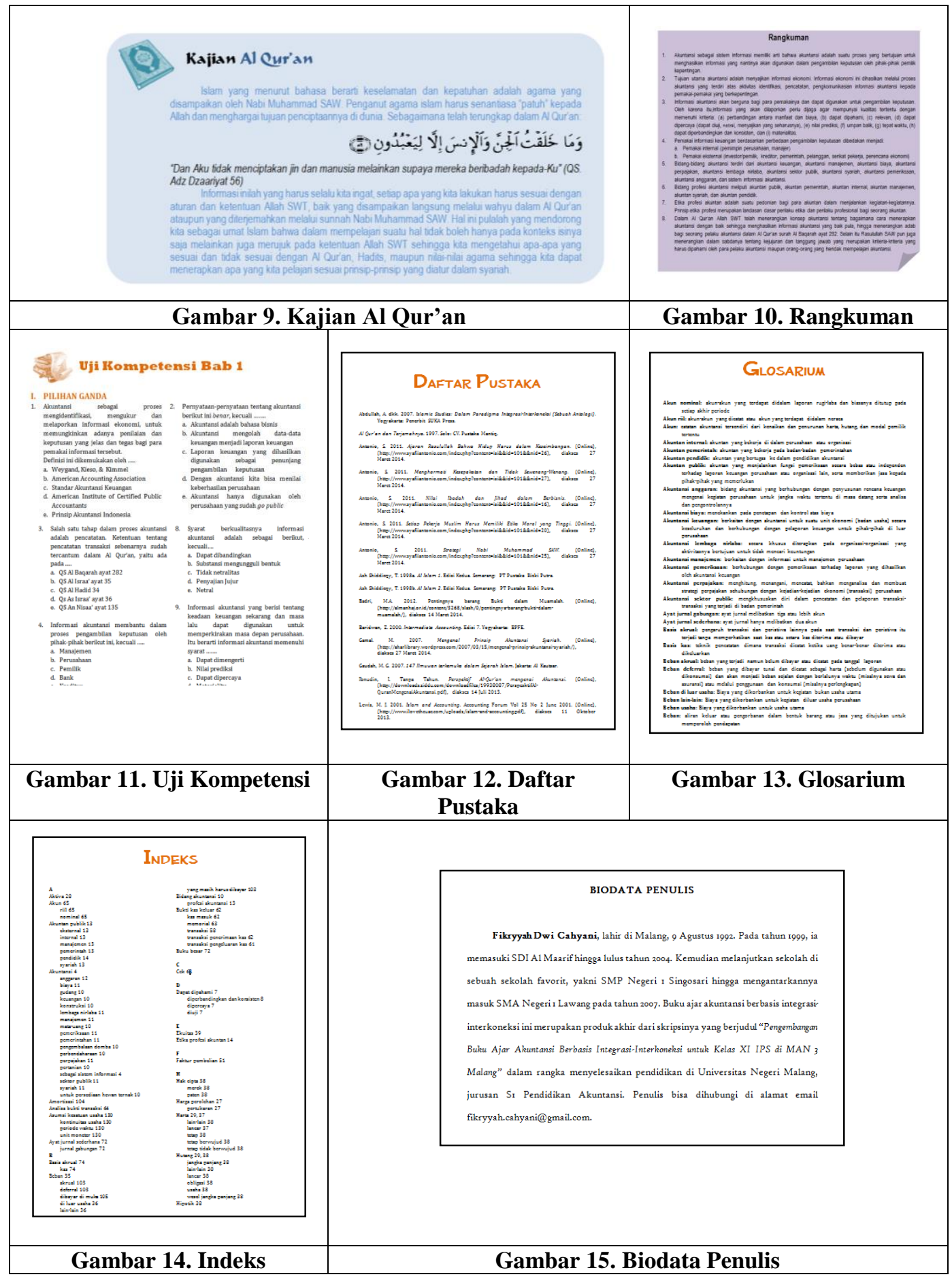

Tahap keempat adalah uji coba lapangan awal. Pada tahap ini, buku ajar yang telah disusun selanjutnya diuji validitasnya oleh satu ahli materi, satu ahli desain bahan ajar, dua orang ahli integrasi-interkoneksi serta diujicobakan pada kelompok kecil subjek pengguna yaitu enam siswa dari kelas XI IPS 1 dan 2 MAN 3 Malang. Hasil dari uji coba lapangan awal ini berupa data kuantitatif dan 
kualitatif. Data kuantitatif yang diperoleh dari ahli materi, ahli desain bahan ajar, ahli integrasi-interkoneksi, dan kelompok kecil siswa berurut-urut sebesar $87,03 \%$, 100\%, 84,06\%, dan 84,57\%. Secara keseluruhan penilaian buku ajar dalam uji coba lapangan awal ini masuk dalam kategori valid atau layak digunakan dengan persentase rata-rata sebesar $88,92 \%$. Data kualitatif berupa komentar dan saran yang digunakan sebagai bahan pertimbangan dalam melakukan revisi produk disajikan pada Tabel 1 berikut ini.

Tabel 1 Ringkasan Data Kualitatif Hasil Validasi Ahli Materi, Ahli Desain Bahan Ajar, Ahli Integrasi-Interkoneksi dan Kelompok Kecil Siswa

\begin{tabular}{|c|c|c|}
\hline No & Nama & Komentar dan saran \\
\hline 1 & $\begin{array}{l}\text { (Ahli Materi) } \\
\text { Drs. Agus Anang } \\
\text { Fauzian, M.Si. }\end{array}$ & $\begin{array}{l}\text { 1. Pengembangan materi sesuai dengan SAK terkini } \\
\text { (menambah wawasan siswa) } \\
\text { 2. Mengacu pada soal UN untuk pengembangan materi dan } \\
\text { soal latihan/ evaluasi } \\
\text { 3. Materi jurnal lebih diperluas }\end{array}$ \\
\hline 2 & $\begin{array}{l}\text { (Ahli Desain Bahan } \\
\text { Ajar) } \\
\text { Dr. Tri Laksiani, S.E., } \\
\text { M.M }\end{array}$ & Cukup jelas \\
\hline 3 & $\begin{array}{l}\text { (Ahli Integrasi- } \\
\text { Interkoneksi) } \\
\text { Dr. Syafaat, M.Ag. }\end{array}$ & $\begin{array}{l}\text { 1. Penyajian ayat Alquran maupun Hadis hendaknya } \\
\text { diperjelas lagi, misalnya dengan memberikan kalimat/ } \\
\text { paragraf keterangan mengapa ayat tersebut berhubungan } \\
\text { dengan materi agar tidak terkesan memaksakan ayat-ayat } \\
\text { tersebut } \\
\text { 2. Hindari untuk mengulang-ulang ayat-ayat Alquran yang } \\
\text { disajikan dalam buku, } 1 \text { ayat maksimal 2x disajikan/ } \\
\text { dipakai } \\
\text { 3. Ayat-ayat Alquran yang disajikan hendaknya lebih } \\
\text { diperjelas lagi mana yang terkait dengan materi, dengan } \\
\text { memberikan garis bawah pada kata yang penting, } \\
\text { 4. Ukuran font Arabic diperbesar menjadi 16-18 } \\
\text { 5. Materi dalam buku ajar dapat ditambah dengan mengkaji } \\
\text { referensi dari Antonio Syafii berkaitan dengan ekonomi } \\
\text { islam }\end{array}$ \\
\hline 4 & $\begin{array}{l}\text { (Ahli Integrasi- } \\
\text { Interkoneksi) } \\
\text { Drs. Untung Wahyudi, } \\
\text { M.Si., Ak., CA. }\end{array}$ & $\begin{array}{l}\text { 1. Untuk literatur akuntansi, jika memungkinkan } \\
\text { menggunakan rujukan terbaru yaitu IFRS atau SAK-ETAP }\end{array}$ \\
\hline 5 & $\begin{array}{l}\text { Kelompok Kecil Subjek } \\
\text { Pengguna }\end{array}$ & $\begin{array}{l}\text { 1. Terdapat beberapa gambar dan ayat yang agak buram } \\
\text { 2. Buku ajar sudah bagus, namun perlu diperbaiki dan } \\
\text { disesuaikan lagi dengan siswa karena tidak semua siswa } \\
\text { yang menggunakan nanti adalah muslim } \\
\text { 3. Sebaiknya ditambah dengan kolom kerja kelompok dan } \\
\text { contoh cerita yang berhubungan dengan akuntansi secara } \\
\text { islami yang mengandung hikmah sehingga bisa memotivasi } \\
\text { siswa } \\
\text { 4. Buku ajar disajikan dengan jelas, menarik karena isinya } \\
\text { berwarna sehingga dapat menimbulkan minat membaca, } \\
\text { serta dapat menambah pengetahuan karena disajikan ayat- } \\
\text { ayat Alquran dan Hadis di dalamnya } \\
\text { 5. Buku ajar memuat materi-materi lain selain akuntansi, }\end{array}$ \\
\hline
\end{tabular}


misalnya hukum islam yang berhubungan dengan ekonomi akuntansi. Namun sampul buku ajar hendaknya diperbaiki agar lebih menarik

6. Tatanan dan materi dalam buku ajar ini sudah bagus, sesuai, dan mudah dipahami karena bahasanya mudah dimengerti. Cover buku hendaknya dibuat lebih menarik lagi

Tahap kelima adalah revisi hasil uji coba lapangan awal. Tahap revisi perlu dilakukan setelah mendapat komentar dan saran dari para ahli dan kelompok kecil siswa dengan tujuan untuk meningkatkan kualitas dari buku ajar yang dikembangkan. Berdasarkan penilaian, komentar dan saran dari ahli materi, maka revisi yang dilakukan adalah: (1) mengembangkan materi akuntansi pada buku ajar dengan merujuk pada SAK terbaru, yaitu IFRS atau SAK-ETAP. Namun materi mengenai SAK terbaru tersebut hanya disampaikan sebatas pada penggantian istilah-istilah dalam akuntansi, (2) mencantumkan beberapa soal akuntansi yang ada pada soal UN ke dalam uji kompetensi, (3) memberikan banyak contoh soal berkaitan dengan pencatatan transaksi ke dalam jurnal, dan (4) menyajikan lembar kerja siswa (berupa kolom-kolom jurnal umum, buku besar, dan sebagainya) agar mempermudah siswa dalam mengerjakan soal uji kompetensi. Revisi terkait dengan desain buku ajar tidak dilakukan karena menurut penilaian, komentar, dan saran dari ahli desain bahan ajar, buku ajar sudah cukup jelas.

Berdasarkan penilaian, komentar, dan saran dari ahli integrasiinterkoneksi, maka revisi yang dilakukan meliputi: (1) memperbesar huruf arabic, (2) memperjelas penyajian ayat Alquran maupun Hadis yang terkait dengan materi dengan memberikan garis bawah pada kata yang penting dan memberikan kalimat atau paragraf keterangan mengapa ayat tersebut berhubungan dengan materi, (3) menyajikan fitur "Wacana Inspiratif" dengan mengkaji referensi dari Antonio Syafii. Berdasarkan penilaian, komentar, dan saran dari siswa maka revisi dilakukan dengan mengatur ulang gambar agar tidak buram dengan menyesuaikan ketika memperbesar gambar, menyajikan lembar kerja siswa, memberikan contoh cerita yang berhubungan dengan akuntansi secara islami yang mengandung hikmah sehingga lebih dapat memotivasi siswa, dan memperbaiki cover buku ajar agar lebih menarik. 
Tahap keenam adalah uji coba lapangan utama. Pada tahap ini uji coba produk dilakukan dengan dua tahapan, siswa terlebih dahulu menilai kelayakan buku ajar akuntansi yang telah dikembangkan kemudian peneliti melakukan onegroup prestest-posttest design, yaitu desain penelitian eksperimen yang dilaksanakan pada satu kelompok saja tanpa kelompok pembanding untuk mengetahui keefektifan buku ajar akuntansi terhadap motivasi dan hasil belajar siswa. Berdasarkan uji coba tahap pertama, diperoleh data persentase kelayakan buku ajar sebesar $77,87 \%$ yang berarti buku ajar cukup valid atau dapat digunakan. Komentar dan saran siswa pada uji coba lapangan utama secara umum mengindikasikan bahwa buku ajar yang telah dikembangkan sudah menarik untuk dipelajari karena materi disajkan dengan jelas dan mudah dipahami, isi buku ajar yang colorfull, dilengkapi dengan gambar-gambar, serta diperkuat dengan kajian Alquran dan Hadis yang dapat menambah pemahaman dan semangat siswa dalam belajar menggunakan buku ini. Meskipun demikian, terdapat beberapa hal yang masih dianggap kurang oleh siswa, seperi ukuran huruf yang kurang besar dan buku yang nampak terlalu tebal.

Tahap uji coba selanjutnya adalah mengukur keefektifan buku ajar akuntansi yang telah dikembangkan. Dalam uji efektivitas ini siswa diberikan angket motivasi, treatment berupa buku ajar akuntansi berbasis integrasiinterkoneksi, pretest, dan posttest. Angket motivasi diberikan untuk mengukur bagaimana tanggapan siswa terhadap pelajaran akuntansi sebelum dan sesudah diberikan treatment buku ajar akuntansi berbasis integrasi-interkoneksi. Angket motivasi yang diberikan merujuk pada angket motivasi Keller (2006). Berikut ini adalah hasil pengolahan data distribusi frekuensi untuk motivasi siswa sebelum dan sesudah diberikan treatment berupa buku ajar akuntansi berbasis integrasiinterkoneksi.

Tabel 2 Distribusi Frekuensi Motivasi Siswa Sebelum dan Sesudah diberikan Treatment

\begin{tabular}{cccccc}
\hline \multirow{2}{*}{ Interval } & \multirow{2}{*}{ Kategori } & \multicolumn{2}{c}{ Sebelum Treatment } & \multicolumn{2}{c}{ Sesudah Treatment } \\
\cline { 3 - 6 } & & Frekuensi & $\mathbf{( \% )}$ & Frekuensi & $\mathbf{( \% )}$ \\
\hline $34-59$ & Tidak Termotivasi & 2 & 12 & 0 & 0 \\
\hline $60-85$ & Kurang Termotivasi & 6 & 35 & 1 & 6 \\
\hline $86-111$ & Termotivasi & 9 & 53 & 13 & 76 \\
\hline $112-137$ & Sangat Termotivasi & 0 & 0 & 3 & 18 \\
\hline & Total & $\mathbf{1 7}$ & $\mathbf{1 0 0}$ & $\mathbf{1 7}$ & $\mathbf{1 0 0}$ \\
\hline
\end{tabular}


Berdasarkan Tabel 2 di atas dapat diketahui bahwa dari 17 siswa yang diteliti, terdapat 7 siswa yang termotivasi, 8 siswa kurang termotivasi, dan 2 siswa tidak termotivasi sebelum diberikan treatment. Sedangkan berdasarkan hasil analisis data statistik deskriptif terhadap motivasi siswa diperoleh nilai rata-rata sebesar 83,21 yang secara umum dapat disimpulkan bahwa rata-rata motivasi siswa sebelum diberikan treatment adalah masuk kategori kurang termotivasi. Sedangkan sesudah diberikan diberikan treatment dapat diketahui bahwa dari 17 siswa yang diteliti, terdapat 3 siswa yang sangat termotivasi, 13 siswa termotivasi, dan 1 siswa kurang termotivasi setelah diberikan treatment. Menurut peneliti satu siswa yang kurang termotivasi ini disebabkan karena siswa menganggap bahwa buku ajar yang dikembangkan dirasa cukup tebal sehingga siswa menjadi kurang tertarik untuk membaca dan mempelajari isi dari buku ajar tersebut. Sedangkan berdasarkan hasil analisis data statisitik deskriptif terhadap motivasi siswa diperoleh nilai rata-rata sebesar 101, 56 yang secara umum dapat disimpulkan bahwa rata-rata motivasi siswa adalah masuk kategori termotivasi.

Soal pretest dan posttest diberikan untuk mengetahui hasil belajar siswa pada materi laporan keuangan, sebelum dan sesudah diberikan treatment. Soal pretest dan posttest sejumlah 11 item pertanyaan berbentuk pilihan ganda. Hasil pengolahan data distribusi frekuensi untuk variabel hasil belajar siswa sebelum dan sesudah diberikan treatment adalah sebagai berikut.

Tabel 3 Distribusi Frekuensi Hasil Belajar Siswa Sebelum dan Sesudah diberikan Treatment

\begin{tabular}{cccccc}
\hline \multirow{2}{*}{ Interval } & \multirow{2}{*}{ Kategori } & \multicolumn{2}{c}{ Sebelum Treatment } & \multicolumn{2}{c}{ Sesudah Treament } \\
\cline { 3 - 6 } & & Frekuensi & $\mathbf{( \% )}$ & Frekuensi & $\mathbf{( \% )}$ \\
\hline $0-20$ & Tidak baik & 7 & 41 & 0 & 0 \\
\hline $21-41$ & Kurang baik & 1 & 6 & 0 & 0 \\
\hline $42-62$ & Cukup baik & 6 & 35 & 2 & 12 \\
\hline $63-83$ & Baik & 3 & 18 & 11 & 65 \\
\hline $84-104$ & Sangat baik & 0 & 0 & 4 & 24 \\
\hline \multicolumn{2}{c}{ Total } & $\mathbf{1 7}$ & $\mathbf{1 0 0}$ & $\mathbf{1 7}$ & $\mathbf{1 0 0}$ \\
\hline
\end{tabular}

Berdasarkan Tabel 3 di atas dapat diketahui bahwa dari 17 siswa yang diteliti terdapat 3 siswa yang memiliki hasil belajar yang baik, 6 siswa memiliki hasil belajar yang cukup baik, dan 7 siswa memiliki hasil belajar yang tidak baik. Berdasarkan hasil analisis data statistik deskriptif terhadap hasil belajar siswa diperoleh nilai rata-rata 37,18. Berdasarkan rata-rata tersebut dapat disimpulkan bahwa rata-rata hasil belajar siswa termasuk dalam kategori kurang baik. Sesudah 
diberikan treatment dapat diketahui bahwa dari 17 siswa yang diteliti terdapat 4 siswa yang memiliki hasil belajar yang sangat baik, 11 siswa memili hasil belajar yang baik, dan 2 siswa memiliki hasil belajar yang cukup baik. Berdasarkan hasil analisis data statistik deskriptif terhadap hasil belajar siswa diperoleh nilai ratarata 75,47 yang dapat disimpulkan bahwa rata-rata motivasi siswa adalah masuk kategori baik.

Data dari angket motivasi siswa dan pretest serta posttest ini kemudian diuji menggunakan uji t (paired-samples $t$ test) untuk mengetahui apakah ada perbedaan antara motivasi dan hasil belajar siswa sebelum dan sesudah diberikan treatment. Hasil uji t untuk motivasi dan hasil belajar siswa dapat ditunjukkan pada tabel berikut ini.

Tabel 4 Hasil Uji $t$ (Paired-Samples $t$ Test) Motivasi Siswa

\begin{tabular}{|c|c|c|c|c|c|c|c|c|c|}
\hline \multicolumn{10}{|c|}{ Paired Samples Test } \\
\hline & & \multicolumn{5}{|c|}{ Paired Differences } & \multirow[b]{4}{*}{$\mathrm{t}$} & \multirow[b]{4}{*}{ df } & \multirow{4}{*}{$\begin{array}{l}\text { Sig. (2- } \\
\text { tailed) }\end{array}$} \\
\hline & & \multirow[b]{3}{*}{ Mean } & \multirow{3}{*}{$\begin{array}{c}\text { Std. } \\
\text { Deviation }\end{array}$} & \multirow{3}{*}{$\begin{array}{l}\text { Std. } \\
\text { Error } \\
\text { Mean }\end{array}$} & \multirow{2}{*}{\multicolumn{2}{|c|}{$\begin{array}{l}\text { 95\% Confidence } \\
\text { Interval of the } \\
\text { Difference }\end{array}$}} & & & \\
\hline & & & & & & & & & \\
\hline & & & & & Lower & Upper & & & \\
\hline $\begin{array}{l}\text { Pair } \\
1\end{array}$ & $\begin{array}{l}\text { MotivasiSebelum } \\
\text { Treatment - } \\
\text { MotivasiSesudah } \\
\text { Treatment }\end{array}$ & -15.000 & 9.618 & 2.333 & -19.945 & -10.055 & -6.431 & 16 & .000 \\
\hline
\end{tabular}

Dari Tabel 4 di atas diketahui bahwa terdapat perbedaan motivasi siswa sebelum dan sesudah diberikan treatment berupa buku ajar akuntansi berbasis integrasi-interkoneksi. Hal ini ditunjukkan dengan angka signifikansi yaitu 0,000 $<0,05$.

Tabel 5 Hasil Uji $t$ (Paired-Samples $t$ Test) Pretest dan Posttest

\begin{tabular}{|c|c|c|c|c|c|c|c|c|c|}
\hline & & & & aired $S$ & mples Te & & & & \\
\hline & & & Paire & Differe & ces & & & & \\
\hline & & & & & $95 \% \mathrm{Co}$ & idence & & & \\
\hline & & & & Std. & Interva & of the & & & \\
\hline & & & Std. & Error & Diffe & nce & & & \\
\hline & & Mean & Deviation & Mean & Lower & Upper & $\mathrm{t}$ & df & Sig. (2-tailed) \\
\hline $\begin{array}{l}\text { Pair } \\
1\end{array}$ & $\begin{array}{l}\text { Pretest - } \\
\text { Posttest }\end{array}$ & -43.176 & 33.240 & 8.062 & -60.267 & -26.086 & -5.356 & 16 & .000 \\
\hline
\end{tabular}

Tabel 5 menunjukkan terdapat perbedaan hasil belajar siswa sebelum dan sesudah diberikan treatment berupa buku ajar akuntansi berbasis integrasiinterkoneksi yang ditunjukkan dengan angka signifikansi yaitu $0,000<0,05$. 
Tahap ketujuh adalah revisi produk akhir. Pada tahap ini yang menjadi rujukan dalam melakukan revisi adalah hasil uji coba lapangan utama. Menurut komentar dan saran dari siswa tulisan dirasa kurang besar, namun saran tersebut tidak dijadikan revisi oleh peneliti, sebab ukuran huruf yang ada sudah sesuai dengan saran dari validator ahli integrasi-interkoneksi. Selain itu juga ada saran dari siswa untuk mempertipis dan meringkas buku ajar karena tampak terlalu tebal serta isinya masih sulit untuk dipahami. Saran dari salah satu siswa ini tidak dijadikan revisi oleh peneliti karena ketebalan buku disebabkan karena penambahan lembar kerja siswa yang merupakan saran dari ahli materi, dan juga terdapat saran teknis yaitu saran untuk menjilid buku, yang akan dilakukan peneliti sebagai penyempurnaan produk akhir.

\section{SIMPULAN}

Produk hasil penelitian dan pengembangan ini adalah bahan ajar cetak berupa buku ajar akuntansi yang dikembangkan dengan memuat SK memahami penyusunan siklus akuntansi perusahaan jasa dan disusun berdasarkan basis integrasi-interkoneksi dengan menyajikan materi pelajaran akuntansi disertai kandungan ayat-ayat Alquran dan Hadis yang sesuai dengan materi tersebut. Buku ajar yang telah disusun terdiri dari beberapa bagian meliputi bagian pendahuluan, isi, dan penutup. Buku ajar ini disusun sebagai alternatif bahan ajar bagi guru yang dapat mendukung keterlaksanaan pembelajaran akuntansi sesuai dengan silabus dan RPP dengan nilai-nilai karakter Qurani yang telah disusun dan juga dapat dijadikan sumber belajar yang dapat digunakan dalam proses pembelajaran sehingga siswa bisa mendapatkan pengetahuan baru tentang keterkaitan antara akuntansi, Alquran, dan Hadis serta dapat meningkatkan motivasi siswa dalam mempelajari akuntansi.

Hasil uji validasi buku ajar yang telah dilakukan oleh ahli materi, ahli desain bahan ajar, ahli integrasi-interkoneksi, dan juga pengguna (siswa) diperoleh rata-rata persentase keseluruhan sebesar $86,71 \%$, yang menunjukkan bahwa buku ajar memiliki kriteria valid dan layak digunakan. Hasil uji efektivitas dengan menggunakan uji-t (paired-samples $t$ test) menunjukkan nilai tingkat signifikansi $(0,000)<(0,05)$ untuk motivasi siswa dan signifikansi $(0,000)<$ 
$(0,05)$ untuk hasil belajar siswa. Sehingga dapat disimpulkan terdapat perbedaan motivasi dan hasil belajar siswa sebelum dan sesudah diberikan treatment berupa buku ajar akuntansi berbasis integrasi-interkoneksi yang menandakan bahwa buku ajar berpengaruh efektif.

Kelebihan buku ajar ini adalah menyajikan materi akuntansi beserta ayatayat Alquran, Hadis, serta sejarah-sejarah Islam yang dapat memberikan pengetahuan baru bagi siswa tentang keterkaitan diantara keduanya sehingga juga dapat meningkatkan motivasi belajar siswa, materi akuntansi dalam buku ajar dikembangkan dengan memuat muatan SAK yang baru, dan buku ajar dapat digunakan oleh sekolah yang menerapkan Kurikulum 2013 karena dalam Kurikulum 2013 terdapat kompetensi inti yang menjadi acuan dari KD dan harus dikembangkan dalam setiap peristiwa pembelajaran secara integratif. Namun demikian, penyajian ayat-ayat Alquran dan Hadis masih sedikit, uji coba pengguna untuk menentukan kelayakan buku ajar hanya dilakukan di MAN 3 Malang saja serta terbatas sampai tahap uji coba lapangan utama sehingga tidak sampai diujicobakan pada tahap uji coba pelaksanaan lapangan dengan skala yang lebih luas, dan uji coba produk untuk mengetahui keefektifan buku ajar hanya dilakukan dengan desain eksperimen yang melibatkan satu kelas saja sebagai kelas eksperimen. Oleh karena itu disarankan agar peneliti selanjutnya menambahkan ayat-ayat Alquran dan Hadis sehingga pengetahuan siswa akan keterkaitan antara Alquran, Hadis, dan akuntansi menjadi lebih luas, uji coba pengguna dan uji coba produk perlu dilakukan pada subjek yang lebih luas, serta untuk eksperimen hendaknya dilakukan dengan menggunakan desain eksperimen kelas kontrol dan kelas eksperimen sehingga keefektifan bahan ajar dapat lebih terpercaya.

\section{DAFTAR RUJUKAN}

Abdullah, A. dkk. 2007. Islamic Studies: Dalam Paradigma IntegrasiInterkoneksi (Sebuah Antologi). Yogyakarta: Penerbit SUKA Press.

Ash Shiddieqy, T. 1998a. Al Islam 1. Edisi Kedua. Semarang: PT Pustaka Rizki Putra. . 1998b. Al Islam 2. Edisi Kedua. Semarang: PT Pustaka Rizki Putra. 
Badan Standar Nasional Pendidikan. 2013. Instrumen Penilaian Buku Teks Pelajaran. (Online), (http://puskurbuk.net/web13/penilaianbtp2013.html), diakses 18 Maret 2014.

Borg, W. 1970a. The Minicourse Instructional Model. Makalah disajikan pada the Annual Meeting of American Educational Research Association, Minneapolis, Maret 1970. Dalam Eric database, (Online), (http://files.eric.ed.gov/fulltext/ED037388.pdf), diakses 25 Januari 2014. 1970b. The $R$ \& $D$ Process as Used in Designing Minicourses. Washington DC: Office of Education (DHEW). Dalam Eric database, (Online), (http://files.eric.ed.gov/fulltext/ED053087.pdf), diakses 25 Januari 2014.

Direktorat Pendidikan Madrasah. 2013. Visi dan Misi. (Online), (http://madrasah.kemenag.go.id/tentang_madrasah/afe4c9a4b6c142eeaf21 6331a138b3d3/visi_misi.html), diakses 11 Oktober 2013.

Keller, J. 2006. Development of Two Measures of Learner Motivation. (Online), (http://olpcorps.wikispaces.com/file/view/ARCSMEA+Partial+Draft+060 222.doc), diakses 22 Januari 2014.

Notodiputro, K. 2013. Kompetensi Dasar Sekolah Menengah Atas (SMA)/Madrasah Aliyah (MA). Kementerian Pendidikan Dan Kebudayaan. (Online), (http://urip.files.wordpress.com/2013/02/kompetensi-inti-dankompetensi-dasar-sma-ma.docx), diakses 19 Januari 2014

Sanjaya, W. 2011. Strategi Pembelajaran Berorientasi Standar Proses Pendidikan. Jakarta: Kencana.

Uno, H. 2009. Teori Motivasi \& Pengukurannya: Analisis di Bidang Pendidikan. Jakarta: PT Bumi Aksara.

Warsono, S. 2012. Al-Qur'an \& Akuntansi: Mengugah Pikiran Mengetuk Relung Kalbu. Yogyakarta: AB Publisher. 